\title{
Water saving strategies assessment on processing tomato cultivated in Mediterranean region
}

\author{
Marcella M. Giuliani, Giuseppe Gatta, Eugenio Nardella, Emanuele Tarantino \\ Department of Agricultural, Food and Environmental Science, University of Foggia, Italy
}

\begin{abstract}
Processing tomato grown in Mediterranean region required high irrigation volume throughout growing season. A two-year study was carried out in order to investigate the effects of deficit irrigation (DI) and regulated deficit irrigation (RDI) on processing tomato cultivated under sub-arid conditions. A comparison between the irrigation management linked to common practice adopted by farmer and the irrigation management based on crop evapotranspiration $\left(\mathrm{ET}_{\mathrm{c}}\right)$ demand was also done. The tomato cv. Genius F1 was cultivated under five water regimes: minimal irrigation $\left(\mathrm{I}_{0}\right)$, as irrigation only at transplanting and during fertilising; $\mathrm{DI}$, to restore $60 \% \mathrm{ET}_{\mathrm{c}}$; $\mathrm{RDI}$, to restore $60 \%-80 \%$ $60 \% \mathrm{ET}_{\mathrm{c}}$ across the three main tomato phenological stages; full irrigation (FI), to restore $100 \% \mathrm{ET}_{c}$; and farmer irrigation (FaI), as irrigation following the subjective farmer method. Compared to FI, under the FaI regime, the seasonal irrigation volume was $31 \%$ and $26 \%$ higher in the 2009 and 2010, respectively, with not significant yield increase between the two water regimes. Among the irrigation regimes, only the RDI showed similar yield values over the two years, although 2010 was climatically less favourable. For the water use efficiency related to the marketable yield $\left(\mathrm{WUE}_{\mathrm{y}}\right)$, among the irrigation regimes, RDI showed the higher value together with FI. Finally, the $K_{y}$ was 0.91 , which indicates moderate water stress tolerance for processing tomato
\end{abstract}

Correspondence: Marcella M. Giuliani, Department of Agricultural, Food and Environmental Science, University of Foggia, via Napoli 25, 71122 Foggia, Italy.

E-mail: marcella.giuliani@unifg.it

Key words: Deficit irrigation; regulated deficit irrigation; water use efficiency; water saving; yield response factor.

Funding: this study was carried out as part of the Project Tecniche di risparmio idrico nella coltivazione del pomodoro da industria, co-funded by the Italian Ministry of Agriculture, within the Italian OIGA Programme.

Conference presentation: SIA XLIV Congress, Bologna, 2015.

Received for publication: 22 December 2015.

Revision received: 26 January 2016.

Accepted for publication: 29 January 2016.

(C) Copyright M.M. Giuliani et al., 2016

Licensee PAGEPress, Italy

Italian Journal of Agronomy 2016; 11:738

doi:10.4081/ija.2016.738

This article is distributed under the terms of the Creative Commons Attribution Noncommercial License (by-nc 4.0) which permits any noncommercial use, distribution, and reproduction in any medium, provided the original author(s) and source are credited. cultivated in Mediterranean regions. In conclusion, the data obtained in the present study demonstrate that in Southern Italy the irrigation planning followed by the farmer does not follow the principles of sustainable irrigation. Moreover, with the adoption of the RDI strategy, it is possible to save about $27 \%$ of water maintaining high $\mathrm{WUE}_{\mathrm{y}}$ value with an increase of fruit quality. The adoption of this regime could be suggested in processing tomato cultivated under Mediterranean climate saving water in both the vegetative and ripening periods.

\section{Introduction}

Italy is one of the major world producers of processing tomato (Solanum lycopersicum L.) and the cultivation of this species is mainly concentrated in the southern regions (Giuliani et al., 2011). However, the south of Italy is characterised by a semi-arid climate making necessary the use of water in the processing tomato cultivation. In the common practices, the farmers' irrigation-scheduling criteria provide for fixed intervals between irrigation supplies (Rinaldi et al., 2011), without take into account the actual soil water content. For this reason farmers generally tend to over-irrigate causing harmful loss of water resources and poor water use efficiency (WUE) (Fereres and Soriano, 2007; Savic et al., 2011). In recent years, agricultural research has shifted its focus from maximising total production to the limiting factors in any production system, which primarily relates to the availability of water. Within this context, deficit irrigation (DI) and regulated deficit irrigation (RDI) has been investigated as a valuable strategy for dry regions where water is the limiting factor for crop cultivation (Fereres and Soriano, 2007; Giuliani et al., 2011). Investigations conducted on DI and RDI strategies in tomato, especially in controlled environments, have provided contrasting results due to the different cultivars or hybrids used and to the phenological period of application of DI treatments (Zegbe-Domínguez et al., 2003; Kuşçu et al., 2014). The literature primarily concerns greenhouse grown tomato and less information is available on DI and RDI effects upon open-field grown tomato. Patanè et al. (2011), in a study conducted upon open-field conditions, reported that the full irrigation [100\% evapotranspiration $\left(\mathrm{ET}_{\mathrm{c}}\right)$ restoration] is required to maximise marketable yield in processing tomato cultivated in semi-arid climate conditions; however, the adoption of DI strategies determined a water saving of about $48 \%$, with yield reduction less than proportional to water deficit.

Also, Kuşç et al. (2014), in a study conducted under sub-humid climate conditions, reported that the highest marketable yield was obtained under fully irrigated conditions and soil water deficits by nonirrigation in one or in more sensitive stages (especially flowering and yield formation) resulted in severe decreases in yield. However, authors concluded that in regions where water scarcity exists, farmers should adopt water saving strategies to achieve economically sustainable crop production. Marouelli and Silva (2007) and Patanè and Cosentino (2010) reported that the effects of soil water deficit at different crop stages on processing tomato fruit yield and quality are not 
yet well defined, because these are relatively complex and site-specific, and they are mainly affected by environmental conditions. Therefore, added studies to better define acceptable levels of water stress to apply in relation to different processing tomato hybrids, irrigation methods and growing areas are necessary. The aim of the present study was to evaluate the effects of DI and RDI regimes on yield, quality, yield water use efficiency $\left(W_{U} E_{y}\right)$ and the yield response factor $\left(K_{y}\right)$ of processing tomato cultivated under sub-arid condition also in relation to physiological parameters. Moreover, water consumption linked to common practice adopted by farmer with respect to irrigation management based on crop evapotranspiration demand was compared.

\section{Materials and methods}

\section{Field trials}

The field experiments were carried out during the 2009 and 2010 crop seasons in Southern Italy. The experimental site was located at 30 m above sea level, at latitude $41^{\circ} 24^{\prime} 27^{\prime \prime} \mathrm{N}$ and longitude $15^{\circ} 45^{\prime} 34^{\prime \prime} \mathrm{E}$. The main physical and chemical soil characteristics of experimental trials are reported in Table 1. The processing tomato cv. Genius F1 [ISI Sementi s.p.a, Fidenza (PR), Italy], characterised by elongated fruits, was cultivated under five irrigation regimes (Table 2). The minimal irri- gation regime $\left(\mathrm{I}_{0}\right)$, irrigated only at transplanting and during fertigation, was included in both years in order to better fitting the $\mathrm{K}_{\mathrm{y}}$ value. The DI was a constant regime, with restoration of $60 \%$ of the maximum tomato $\mathrm{ET}_{\mathrm{c}}$ throughout the crop cycle. The RDI was a variable irrigation regime that provided restoration of $60 \%, 80 \%$ and $60 \%$ of the maximum $\mathrm{ET}_{\mathrm{c}}$ through the following three main phenological stages of the crop cycle, respectively: from plant establishment to flowering of the first truss $\left(\mathrm{PS}_{1}\right)$; from flowering of the first truss to fruit breaking colours of the first truss $\left(\mathrm{PS}_{2}\right)$; and from fruit breaking colours of the first truss to harvest $\left(\mathrm{PS}_{3}\right)$. The full irrigation (FI) provided the restoration of $100 \%$ $\mathrm{ET}_{\mathrm{c}}$. Finally, the farmer irrigation (FaI) regime followed a method based on the farming routine and the farmer's intuition, whereby the farmer decided on when to irrigate and how much water to apply. The irrigation volumes applied under each irrigation treatment throughout the 2009 and 2010 tomato growing seasons are shown in Table 2 . The experiment was arranged in a randomised complete block design with four replicates; each plot covered a $30-\mathrm{m}^{2}$ surface. Transplanting was carried out on 12 May 2009, and on 7 May 2010, in paired rows spaced at $1.8 \mathrm{~m}$. The distance between the paired rows was $0.5 \mathrm{~m}$, and the distance between the plants within the rows was $0.4 \mathrm{~m}$. The final plant density was 2.7 plants $\mathrm{m}^{-2}$. Each irrigation regime covered three pair rows and all the parameters were measured only in the central pair rows. During the two crop seasons, standard agricultural practices were performed. For each year, the soil was ploughed during the winter to a depth of $0.45 \mathrm{~m}$, and a few days before transplanting, the soil was well harrowed. Basic fertil-

Table 1. Main soil physical and chemical properties in the two experimental years.

\begin{tabular}{lccc} 
Properties & Unit of measurement & 2009 & 2010 \\
Sand & $\%$ & 28 & 31 \\
Silt & $\%$ & 23 & 51 \\
\hline Clay & $\%$ & 19 & 1.6 \\
Organic matter (Walkley-Black method) & $\%$ & 0.15 & 0.13 \\
\hline Total N (Kjeldhal method) & $\%$ & 28 & 25 \\
Available P (Olsen method) & ppm & 458 & 460 \\
\hline Exchangeable K (ammonium acetate method) & ppm & 34 & 35 \\
Field capacity (-0.03 MPa) & $\%$ d.w. & 17 & 1.4 \\
\hline Wilting point $(-1.5 \mathrm{MPa})$ & $\%$ d.w. & 1.2 & 1.2 \\
Bulk density & $\mathrm{t} \mathrm{m}^{-3}$ & & \\
\hline
\end{tabular}

N, nitrogen; P, phosphorus; K, potassium.

Table 2. Duration of tomato phenological stages and seasonal irrigation volumes applied in the 2009 and 2010 growing seasons.

\begin{tabular}{|c|c|c|c|c|c|c|c|}
\hline \multirow[t]{2}{*}{ Year } & \multirow[t]{2}{*}{ Phenological } & \multirow[t]{2}{*}{$\begin{array}{l}\text { Stage duration } \\
\text { (days) }\end{array}$} & \multicolumn{5}{|c|}{$\begin{array}{l}\text { Irrigation regimes } \\
(\mathrm{mm})\end{array}$} \\
\hline & & & $\mathrm{I}_{0}$ & DI & RDI & FI & FaI \\
\hline \multirow[t]{5}{*}{2009} & $\mathrm{PS}_{0}$ & 9 & 26.80 & 26.80 & 26.80 & 26.80 & 26.80 \\
\hline & $\mathrm{PS}_{1}$ & 20 & 8.50 & 66.30 & 66.30 & 110.50 & 110.30 \\
\hline & $\mathrm{PS}_{2}$ & 39 & 12.80 & 140.40 & 187.20 & 234.00 & 377.20 \\
\hline & $\mathrm{PS}_{3}$ & 30 & - & 89.70 & 89.70 & 149.40 & 166.30 \\
\hline & Total & 98 & 48.10 & 323.20 & 370.00 & 520.70 & 680.60 \\
\hline \multirow[t]{5}{*}{2010} & $\mathrm{PS}_{0}$ & 10 & 16.00 & 16.00 & 16.00 & 16.00 & 16.00 \\
\hline & $\mathrm{PS}_{1}$ & 24 & 15.10 & 59.10 & 59.10 & 98.41 & 91.00 \\
\hline & $\mathrm{PS}_{2}$ & 32 & 13.50 & 171.30 & 228.40 & 285.50 & 319.40 \\
\hline & $\mathrm{PS}_{3}$ & 28 & - & 87.00 & 87.00 & 144.90 & 260.70 \\
\hline & Total & 94 & 44.60 & 333.40 & 390.50 & 544.81 & 687.10 \\
\hline
\end{tabular}

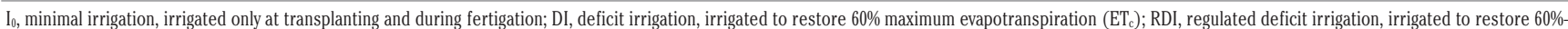
$80 \%-60 \% \mathrm{ET}_{\mathrm{c}}$ for the three main phenological stages, respectively; FI, full irrigation, irrigated to restore $100 \% \mathrm{ET}_{c}$; FaI, farmer irrigation, irrigated following subjective method based on routine use and intuition; $\mathrm{PS}_{0}$, from transplanting to plant establishment; $\mathrm{PS} 1$, from plant establishment to flowering of first truss; $\mathrm{PS}_{2}$, from flowering of first truss to fruit breaking colours of first truss; $\mathrm{PS}_{3}$, from fruit breaking colours of first truss to harvest. 
isation was achieved using $72 \mathrm{~kg} \mathrm{ha}^{-1} \mathrm{~N}$ and $128 \mathrm{~kg} \mathrm{ha}^{-1} \mathrm{P}$, and during the crop cycle, $82 \mathrm{~kg} \mathrm{ha}^{-1} \mathrm{~N}$ was added by fertigation. Pest and weed control was performed according to current management practices. A drip irrigation system was used for the irrigation, as a single plastic pipe arranged in the middle of each paired row, with drippers of $2 \mathrm{~L} \mathrm{~h}^{-1}$ flow rate spaced every $0.4 \mathrm{~m}$. The crop was hand harvested when the ripe fruit rate reached about 95\% (17 Aug 2009; 5 Aug 2010).

\section{Irrigation regimes}

For DI, RDI and FI regimes, irrigation was performed every time the sum of daily $\mathrm{ET}_{\mathrm{c}}$, excluding the useful rainfall, was equal to $40 \%$ of the maximum available soil water content in the $0-60 \mathrm{~cm}$ of soil depth, where most of roots are expected to grow (Wang et al., 2015). The daily $\mathrm{ET}_{\mathrm{c}}$ was calculated according to a two-step approach $\left(\mathrm{ET}_{\mathrm{c}}=\mathrm{ET}_{0} \times \mathrm{K}_{\mathrm{c}}\right)$ where $\mathrm{ET}_{0}$ is the reference evapotranspiration according to PenmanMonteith's equation (Jensen et al., 1990; Allen et al., 1998) and $\mathrm{K}_{\mathrm{c}}$ is the crop coefficient, as detected in an environment similar to our experimental site (Tarantino and Onofri, 1991). $\mathrm{ET}_{0}$ was calculated using daily data from meteorological station (Delta-T Devices Ltd., Cambridge, UK) located about $50 \mathrm{~m}$ from the experimental field. The seasonal tomato water consumption, under the different irrigation treatments, was calculated using the soil water balance equation (ElHendawy and Schmidhalter, 2010):

$$
\mathrm{ET}=\mathrm{I}+\mathrm{P}+\mathrm{Cr}-\mathrm{R}-\mathrm{D} \pm \Delta \mathrm{S}
$$

where:

ET is seasonal tomato evapotranspiration (mm); I is the irrigation water amount $(\mathrm{mm}) ; \mathrm{P}$ is the precipitation $(\mathrm{mm}) ; \mathrm{Cr}$ is the capillary rise $(\mathrm{mm}) ; \mathrm{R}$ is the amount of runoff $(\mathrm{mm})$; $\mathrm{D}$ is the amount of drainage water $(\mathrm{mm})$; and $\Delta \mathrm{S}$ is the difference between soil water content values, determined gravimetrically, at planting and at harvesting (mm) in the first $0.6 \mathrm{~m}$ depth. In this study $\mathrm{Cr}$ was considered to be zero due to the high depth of groundwater. Surface runoff was assumed to be negligible because there have not been intense rainfall events such as to cause run-off. Drainage below the root zone was assumed zero, since water applied with each irrigation plus rainfall amounts were not sufficient to bring the soil moisture level over the field capacity within the root zone during the growing season (Istanbulluoglu et al., 2009; El-Hendawy and Schmidhalter, 2010). With the exception of $\mathrm{I}_{0}$, in the second year the irrigation volumes were always higher with respect to the first year (Table 2). The highest irrigation volume was used under the FaI regime (680.6 $\mathrm{mm}$ and $687.1 \mathrm{~mm}$ in 2009 and 2010, respectively), while under the FI regime, the seasonal irrigation volume was $520.7 \mathrm{~mm}$ and $544.8 \mathrm{~mm}$ in 2009 and 2010 , respectively in line with the irrigation volumes that are generally applied in Southern Italy (Rinaldi and Rana, 2004).

\section{Weather conditions}

The temperature, rainfall and $\mathrm{ET}_{0}$ data of the two experimental years (2009 and 2010) are reported in Figure 1. The maximum (Tmax) and
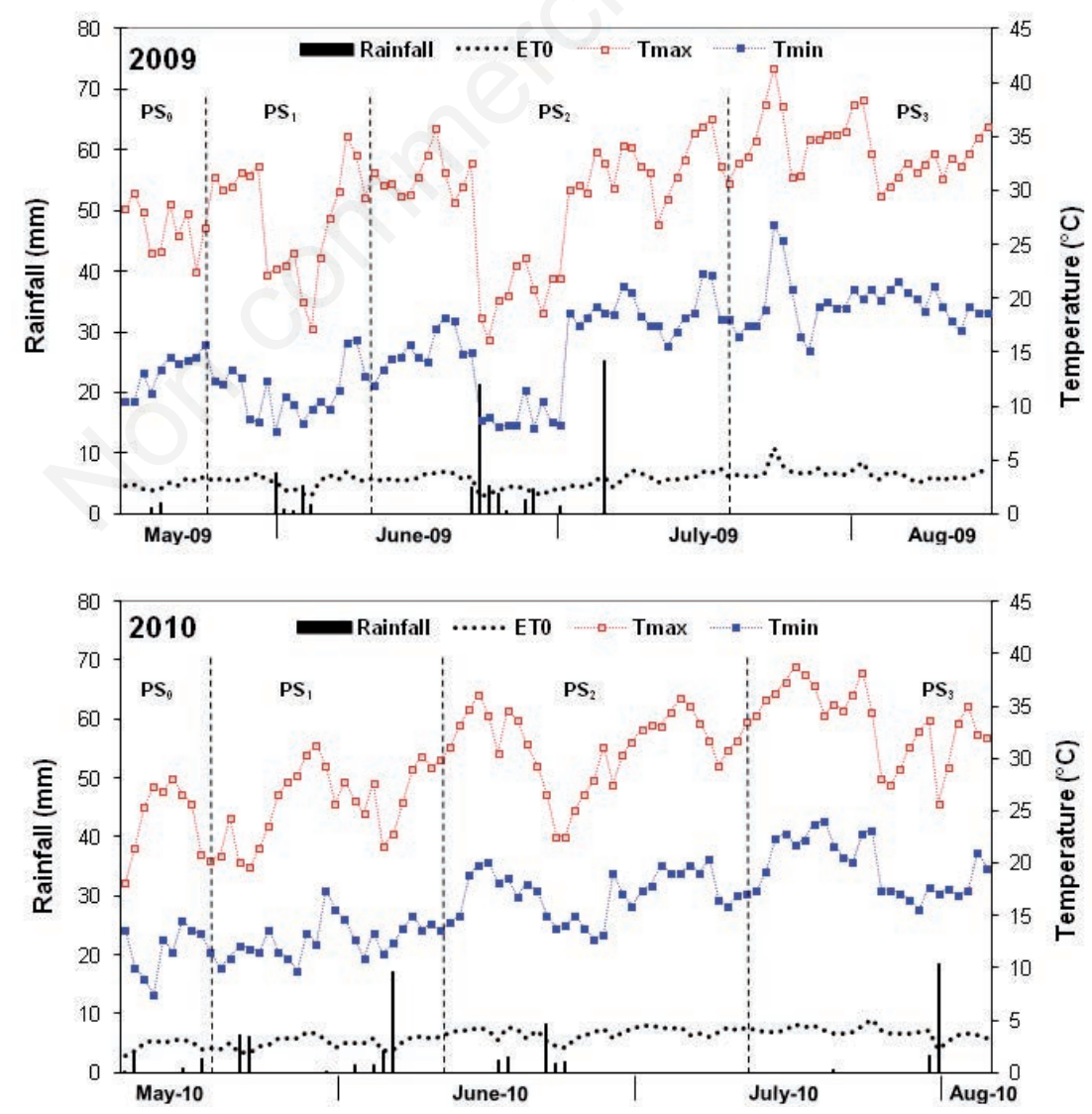

Figure 1. Main climatic parameters recorded during the two processing tomato-growing seasons (2009, 2010). The four different phenological stages $\left(\mathrm{PS}_{0}, \mathrm{PS}_{1}, \mathrm{PS}_{2}, \mathrm{PS}_{3}\right)$ are also highlighted. 
minimum (Tmin) temperatures during the two tomato crop cycle, were similar in $\mathrm{PS}_{1}$ and $\mathrm{PS}_{3}$ stages, while during the $\mathrm{PS}_{2}$ the Tmax and the Tmin were higher in the 2010 season with respect to the 2009. Also the daily $\mathrm{ET}_{0}$ during the two processing tomato-growing seasons was similar, ranging from $4.5 \mathrm{~mm}$ to $7.9 \mathrm{~mm}$ in 2009 and from $4.3 \mathrm{~mm}$ and 7.4 $\mathrm{mm}$ in 2010. Finally, the total rainfall was $84 \mathrm{~mm}$ in 2009 and $80.9 \mathrm{~mm}$ in 2010. Moreover, the two years differed in the rainfall distribution especially during the $\mathrm{PS}_{2}$ phenological stage, when $67.2 \mathrm{~mm}$ fell in 2009 and only $16.3 \mathrm{~mm}$ in 2010 .

\section{Physiological, quantitative and qualitative parameters measurements}

During the $\mathrm{PS}_{2}$ phenological stage, the canopy and air temperatures and stomatal conductance were measured between 12:00 a.m. and 01:00 p.m. (i.e., at maximum sunlight intensity) at 15 and 21 July in 2009, and at 6 and 13 July in 2010. Crop and air temperatures were recorded using an infrared thermometer with a spectral response of 8 $\mu \mathrm{m}$ to $14 \mu \mathrm{m}$ (Scheduler Model 2; Delta-T Devices Ltd.), and were used to calculate the canopy temperature depression (CTD), expressed as crop temperature minus air temperature (Bahar et al., 2008). Stomatal conductance (gs, mol m $\mathrm{m}^{-2} \mathrm{~s}^{-1}$ ) of the lower side of the leaf (Sobeih et al., 2004) of the first fully expanded leaf (three leaves per replicate, selected at random) was measured using a steady-state diffusion porometer (Model SC-1; Decagon Devices, Inc., Pullman, WA, USA). At harvest, for twenty plants per plot, the marketable tomato yield, fruit mean weight, and soluble solids were evaluated. The marketable yield was measured considering only the red and disease-free fresh fruit. Ripened fruit of the first and second trusses were used for the quality analysis. The tomatoes were washed under running tap water to remove dirt, and dried with absorbent paper. They were then analysed for single fruit weight ( $\mathrm{g}$ ) and soluble solids. The soluble solids ( ${ }^{\circ} \mathrm{Brix}$ ) were measured with a digital refractometer [model DBR35, XS Instruments; Giorgio Bormac s.r.l., Carpi (M0), Italy].

The yield water use efficiency $\left(\mathrm{kg} \mathrm{m}^{-3}\right)$ was calculated from fresh marketable yield and seasonal water consumption according to Lovelli et al. (2007).

Moreover, for all the irrigation regimes, with the exception of FaI, the $\mathrm{K}_{\mathrm{y}}$ was calculated as in Equation (2) (Stewart et al., 1977):

$$
1-Y_{a} / Y_{m}=K_{y}\left(1-E_{a} / E_{m}\right)
$$

where:

$\mathrm{Y}_{\mathrm{a}}\left(\mathrm{Mg} \mathrm{ha}^{-1}\right)$ is the yield obtained for $\mathrm{I}_{0}, \mathrm{DI}, \mathrm{RDI}$ and $\mathrm{FI}$;

$\mathrm{Y}_{\mathrm{m}}\left(\mathrm{Mg} \mathrm{ha}^{-1}\right)$ is the maximum yield obtained for FI regime;

$\mathrm{ET}_{\mathrm{a}}(\mathrm{mm})$ is the actual seasonal crop evapotranspiration for each water regime considered;

$\mathrm{ET}_{\mathrm{m}}(\mathrm{mm})$ is the maximum seasonal crop evapotranspiration measured for FI regime.

\section{Statistical analysis}

The Bartlett test confirmed the homogeneity of variance between the years so that a combined statistical analysis was applied. The physiological, productive and qualitative data were analysed using analysis of variance, according to the applied experimental design. When significant effects were detected, mean multiple comparisons were performed according to Tukey's test. The data were analysed using the JMP package, version 8.2 (SAS Institute Inc., Cary, NC, USA). The graphical representations were produced using the SigmaPlot software (Systat Software, Chicago, IL, USA).

\section{Results}

\section{Physiological, quantitative and qualitative parameters}

In Table 3 the physiological parameters evaluated during the $\mathrm{PS}_{2}$ stage are reported. For both CTD and gs differences were found between the two years and among the irrigation regimes, while not significant differences emerged for the interaction. Between the two years under study, a lower CTD was observed for the 2009 season, while among the irrigation regimes, both the FI and the FaI regimes had the lowest CTD ( 0.18 and $0.16^{\circ} \mathrm{C}$, respectively). Both RDI and DI had a CTD significantly higher from those obtained for FI and FaI regimes

As for the gs the highest value was observed in the first year. Among the irrigation regimes the FI and FaI regimes had values significantly higher than those of RDI and DI.

The marketable yield is reported in Table 4. Significant differences were found for the year, the irrigation regimes and their interaction. In particular, for all the irrigation regimes the marketable yield was higher in 2009 than in 2010. In both years the FaI regime gave the highest values, but between FaI and FI there were not significant differences. Among the regimes, the DI showed always the lowest value, while RDI showed value significantly higher than DI only in the 2010; moreover RDI was the only regime showing similar values in the two years.

Relative to $\mathrm{WUE}_{\mathrm{y}}$ (Table 4), significant effects were observed only for the year and irrigation regime factors. The first year was better by $20 \%$ in $W_{\text {UE }}$ than the second one; among the irrigation regimes the RDI treatment showed the highest value similar to FI, while the regime linked to the farmer showed the lowest.

For the fruit mean weight significant differences were found for the year, the irrigation regimes and their interaction. Relative to the interaction, in the first year the weight values increased with the irrigation volume increasing from DI to FaI, while in 2010 the higher value was relative to RDI.

Relative to the soluble solids content, in both years the FaI produced fruits with the lower values. In 2009, the RDI regime showed the highest soluble solids, while in 2010 , the highest soluble solids value was observed for the DI regime.

Finally, the $\mathrm{K}_{\mathrm{y}}$ coefficient relative to the 2009 and 2010 , determined

Table 3. Effects of the year and the irrigation regime on the canopy temperature depression and the stomatal conductance (gs).

\begin{tabular}{lcc} 
Treatments & CID $\left({ }^{\circ} \mathrm{C}\right)$ & gs $\left(\mathrm{mol} \mathrm{m}^{-2} \mathrm{sec}^{-1}\right)$ \\
Year & & \\
2009 & $0.40^{\mathrm{b}}$ & $0.96^{\mathrm{a}}$ \\
2010 & $1.02^{\mathrm{a}}$ & $0.78^{\mathrm{b}}$ \\
Irrigation regime & & \\
DI & $1.65^{\mathrm{a}}$ & $0.75^{\mathrm{b}}$ \\
RDI & $0.86^{\mathrm{b}}$ & $0.70^{\mathrm{b}}$ \\
FI & $0.18^{\mathrm{c}}$ & $1.05^{\mathrm{a}}$ \\
FaI & $0.16^{\mathrm{c}}$ & $1.05^{\mathrm{a}}$ \\
\hline Significance & & \\
$\quad$ Year & $*$ & $* *$ \\
Irrigation regime & $* * *$ & $* * *$ \\
Year $\times$ Irrigation regime & $\mathrm{ns}$ & $\mathrm{ns}$ \\
\hline
\end{tabular}

CTD; canopy temperature depression; DI, deficit irrigation, irrigated to restore $60 \%$ maximum evapotranspiration (ETc); RDI, regulated deficit irrigation, irrigated to restore $60 \%-80 \%-60 \% \mathrm{ET}_{\mathrm{c}}$ for the three main phenological stages, respectively; FI, full irrigation, irrigated to restore $100 \% \mathrm{ET}_{\mathrm{c}}$; FaI, farmer irrigation, irrigated following subjective method based on routine use and intuition. ${ }^{\mathrm{a}-\mathrm{c}} \mathrm{In}$ each column, means followed by equal letters are not significantly different for $\mathrm{P} \leq 0.05$ (Tukey's test); ${ }^{*} \mathrm{P} \leq 0.05 ;{ }^{*} \mathrm{P} \leq 0.01$ ***P $\leq 0.001 ;$ ns, not significant. 
according to Equation (2), is reported in Figure 2. Under our experimental conditions, $\mathrm{K}_{\mathrm{y}}$ was slightly lower than 1.0 and equal to 0.91 indicating a productivity behaviour that allows a reduced water supply with low effects on yield. Moreover, a linear regression was found between $\mathrm{K}_{\mathrm{y}}$ and the physiological parameters (Figure $3 \mathrm{~A}$ and $\mathrm{B}$ ). $\mathrm{K}_{\mathrm{y}}$ was positively related to CTD, and negatively with stomatal conductance.

\section{Discussion}

The two years under study differed especially for the maximum temperature trend during the $\mathrm{PS}_{2}$ stage, from flowering of first truss to fruit breaking colours of first truss. In this period, the maximum temperature were always higher in the second year than in the first one causing also a shortening of this phenological stage (39 days in 2009 vs 32 in 2010). Moreover, in the second year almost the fifty percent of the days in $\mathrm{PS}_{2}$ stage were characterised from temperature higher than $32^{\circ} \mathrm{C}$ that is a threshold temperature related to the flower abortion (Benton Jr, 2007) (8 days in 2009 vs 14 days in 2010).

\section{Physiological, quantitative and qualitative parameters}

The $\mathrm{PS}_{2}$ stage, is the most important in tomato because the plants set up the number of flowers and so the fruits; but it is also a stage in which the plants are more sensible to the climatic stress (Zegbe et al., 2006; Kuşçu et al., 2014). During this stage, two physiological parameters, CTD and the leaf gs, both related to the water plant status, have been measured (Table 3 ). The CTD parameter represents the difference between the crop temperature and the air temperature; a high CTD indicates a high canopy temperature, which is an indicator of plant water stress (Idso et al., 1981). The higher CTD value observed for the 2010 season could be related to the higher temperature trends registered in this stage with respect to 2009 . For the irrigation regimes, the lowest values were observed for FaI and FI regimes, and the highest for DI showing that the plants cultivated under this regime probably were not able to transpire sufficient water to cool the leaves below the air temperature, thus causing stress (Böcs et al., 2009).

The gs indicates the degree of stomata opening. Also in this case the data relative to the 2010 showed a worse plant water status with respect to 2009. Moreover, both DI and RDI showed lower gs than the FI and FaI regimes, which indicates their stomatal closure. These data are consis-

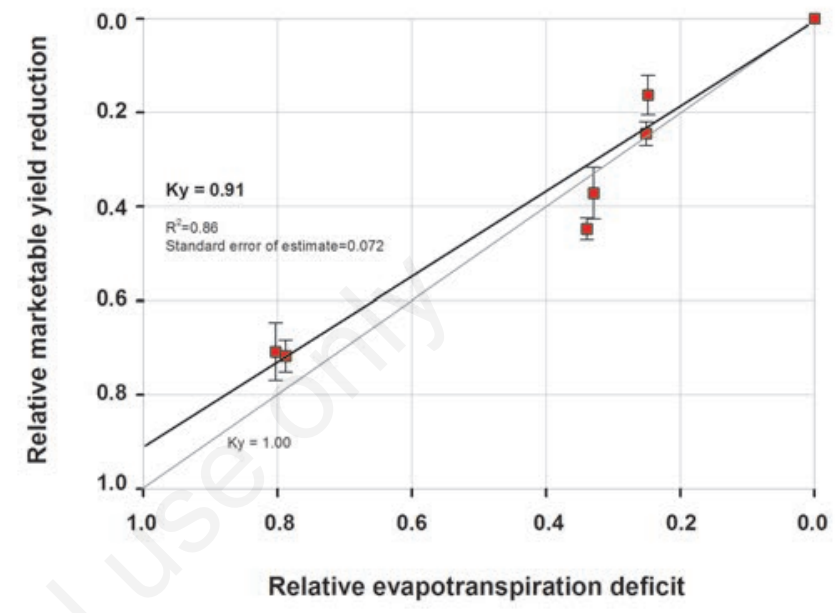

Figure 2. Relationship between the relative yield reduction (1$\left.Y_{a} / Y_{m}\right)$ and the relative evapotranspiration deficit (1-ETa/ETm) for the two crop cycles. Data are means \pm standard error. $K_{y}=1$ is shown as a reference line.

Table 4. Effects of year, irrigation regime and their interaction on the marketable yield, water use efficiency, single fruit weight and soluble solids.

\begin{tabular}{|c|c|c|c|c|}
\hline Condition & $\begin{array}{l}\text { Marketable yield } \\
\qquad\left(\mathrm{Mg} \mathrm{ha}^{-1}\right)\end{array}$ & $\begin{array}{l}\text { WUEy } \\
\left(\mathrm{kg} \mathrm{m}^{-3}\right)\end{array}$ & $\begin{array}{l}\text { Mean fruit weight } \\
\text { (g) }\end{array}$ & $\begin{array}{c}\text { Soluble solids } \\
\text { ('Brix) }\end{array}$ \\
\hline $\begin{array}{l}\text { Year } \\
2009 \\
2010\end{array}$ & $\begin{array}{l}72.9^{\mathrm{a}} \\
60.1^{\mathrm{b}}\end{array}$ & $\begin{array}{l}13.3^{\mathrm{a}} \\
10.6^{\mathrm{b}}\end{array}$ & $\begin{array}{l}54.5 \\
54.9\end{array}$ & $\begin{array}{l}5.7^{\mathrm{b}} \\
6.8^{\mathrm{a}}\end{array}$ \\
\hline $\begin{array}{l}\text { Irrigation regime } \\
\text { DI } \\
\text { RDI } \\
\text { FI } \\
\text { FaI } \\
\end{array}$ & $\begin{array}{l}45.6^{\mathrm{c}} \\
60.7^{\mathrm{b}} \\
76.9^{\mathrm{a}} \\
82.8^{\mathrm{a}}\end{array}$ & $\begin{array}{l}11.2^{\mathrm{bc}} \\
13.3^{\mathrm{a}} \\
12.6^{\mathrm{ab}} \\
10.8^{\mathrm{c}}\end{array}$ & $\begin{array}{l}47.6^{\mathrm{b}} \\
57.4^{\mathrm{a}} \\
55.2^{\mathrm{a}} \\
58.8^{\mathrm{a}}\end{array}$ & $\begin{array}{l}7.0^{\mathrm{a}} \\
6.6^{\mathrm{ab}} \\
6.2^{\mathrm{b}} \\
5.2^{\mathrm{c}}\end{array}$ \\
\hline $\begin{array}{l}\text { Year } \times \text { Irrigation regime } \\
\mathrm{DI}{ }_{(2009)} \\
\mathrm{RDI}_{(2009)} \\
\mathrm{FI}_{(2009)} \\
\mathrm{FaI}_{(2009)} \\
\mathrm{DI}_{(2010)} \\
\mathrm{RDI}_{(2010)} \\
\mathrm{FI}_{(2010)} \\
\mathrm{FaI}_{(2010)}\end{array}$ & $\begin{array}{l}53.1^{\mathrm{e}} \\
63.9^{\mathrm{de}} \\
84.9^{\mathrm{ab}} \\
89.7^{\mathrm{a}} \\
38.1^{\mathrm{f}} \\
57.6^{\mathrm{e}} \\
68.9^{\mathrm{cd}} \\
75.9^{\mathrm{bc}}\end{array}$ & $\begin{array}{c}13.0 \\
14.1 \\
14.0 \\
11.7 \\
9.2 \\
12.2 \\
11.0 \\
9.9\end{array}$ & $\begin{array}{c}50.0^{\mathrm{de}} \\
52.2^{\mathrm{cd}} \\
55.3^{\mathrm{bcd}} \\
60.6^{\mathrm{ab}} \\
45.2^{\mathrm{ed}} \\
62.7^{\mathrm{a}} \\
55.1^{\mathrm{bcd}} \\
56.0^{\mathrm{abc}}\end{array}$ & $\begin{array}{l}6.1^{\text {cde }} \\
6.5^{\mathrm{bcd}} \\
5.6^{\mathrm{e}} \\
4.6^{\mathrm{f}} \\
7.9^{\mathrm{a}} \\
6.7^{\mathrm{bc}} \\
6.9^{\mathrm{b}} \\
5.8^{\mathrm{de}}\end{array}$ \\
\hline $\begin{array}{l}\text { Significance } \\
\text { Year } \\
\text { Irrigation regime } \\
\text { Year } \times \text { Irrigation regime }\end{array}$ & $\begin{array}{c}* * * \\
* * * \\
*\end{array}$ & $\begin{array}{l}* * \\
* * \\
\text { ns }\end{array}$ & $\begin{array}{l}\mathrm{ns} \\
* * * \\
* * *\end{array}$ & $\begin{array}{c}* * * \\
* * * \\
* *\end{array}$ \\
\hline
\end{tabular}

$\mathrm{WUE}_{\mathrm{y}}$, water use efficiency related to the marketable yield; DI, deficit irrigation, as irrigation to restore $60 \%$ maximum evapotranspiration (ET $\mathrm{c}$ ); $\mathrm{RDI}$, regulated DI, as irrigation to restore $60 \%-80 \%-60 \% \mathrm{ET}_{\mathrm{c}}$ across the three main growing stages; FI, full irrigation, as irrigation to restore $100 \% \mathrm{ETc}$; FaI, farmer irrigation, irrigated following subjective method based on routine use and intuition. ${ }^{\text {a-f }}$ In each column, means followed by equal letters are not significantly different for $\mathrm{P} \leq 0.05$ (Tukey's test); ${ }^{*} \leq 0.05 ;{ }^{*} \mathrm{P} \leq 0.01 ;{ }^{*} * \mathrm{P} \leq 0.001$; ns, not significant. 
tent with those of Böcs et al. (2009) and Nardella et al. (2012) who reported that the stomata of the regularly irrigated tomato plants were opened more widely, because of the high turgor capacity; in contrast, the stressed plants showed the opposite behaviour, to avoid unnecessary water loss.

Relative to the marketable yield also the lower value observed in 2010 with respect to 2009 (Table 4) was probably due to the higher temperatures observed during the $\mathrm{PS}_{2}$ phenological stage (Figure 1) that could be determined flower abortion influencing the number of fruits. In both years, there were no significant differences between the FI and FaI marketable yields; the yield increases observed from FI to FaI were only $6 \%$ in 2009 and $10 \%$ in 2010 . These data have to be discussed also in relation to the irrigation volume used. In particular, the farmer used $31 \%$ and $26 \%$ more water than the optimal irrigation regime (FI) in 2009 and 2010, respectively (Table 2), and thus compares unfavourably with the yield increases observed. These data demonstrate that the farmer tended to over-irrigate the tomato crop, and that most of this extra water used for the $\mathrm{FaI}$ regime did not provide any significant increment in the marketable yield. This is of particular interest, because in many areas of the Mediterranean region, such as Southern Italy, the water resources are seriously depleted (García-Tejero et al., 2011). Across both of these years, the DI and RDI regimes affected the marketable yield, in agreement with the literature (Favati et al., 2009; Kuşçu et al., 2014). RDI regime produced always more than DI regime. In particular, in the 2009 season the RDI regime showed a marketable yield that was increased by $20 \%$ over the DI regime in 2009 and by $51 \%$ in the 2010, which was characterised by higher temperature during $\mathrm{PS}_{2}$ stage. The differences observed between DI and RDI for both of the years was due to the higher irrigation volume used during the $\mathrm{PS}_{2}$ stage in the RDI regime, confirming the importance of the irrigation during the sensitive flowering and fruit formation stage, as reported in the literature (Zegbe et al., 2006; Kuşçu et al., 2014). Moreover, our results highlight how positive effects of RDI with respect to DI are more evident when the climatic conditions are more stressed. Our data are also in agreement with different studies showing that different levels of water deficit can decrease tomato yield to different extents, depending on the period when it occurs and the degree of the water stress that results (Zegbe et al., 2006; Patanè et al., 2011; Chen et al., 2013).

Finally, it is important to underline that only the RDI has kept constant the marketable yield value over the two years (63.9 and $57.6 \mathrm{Mg}$ ha $^{-1}$ in 2009 and 2010 , respectively) despite 2010 being climatically less favourable. Due to this, compared to the FI, in 2010 the marketable yield reductions in RDI was only $16 \%$ (against the $25 \%$ of the first year) accompanied by water savings about of $28 \%$ (Table 2 ).

The good performance of RDI regime was confirmed also by the WUE $_{\mathrm{y}}$. The highest value was observed for RDI regime significantly higher than DI and FaI. These results are in agreement with ZegbeDomínguez et al. (2003) and Savic et al. (2011), who reported positive effects of RDI on WUE in processing tomato. However, in tomato the effects of water stress on the WUE have been contrasting. Rinaldi $e t$ al. (2011) and Zheng et al. (2013) did not find any significant differences in WUE among the different water regimes that they used. In a twoyear greenhouse grown fresh market tomato study, Nuruddin et al. (2003) reported significantly higher WUE under no water stress treatment with respect to others deficit irrigation treatments in the first year of their experiment, and no significant differences between their no water stress and four mild and moderate water stress treatments in their second year. Conversely, in the most of the literature, increases in the WUE in tomato under water deficit conditions have also been reported (Topcu et al., 2007; Favati et al., 2009; Giuliani et al., 2011; Patanè et al., 2011; Chen et al., 2013). Finally, in our study the lowest WUE $_{\mathrm{y}}$ value was observed for FaI, showing once again that with this regime the farmer used too much water in relation to the marketable yield obtained.

Also for the fruit mean weight in 2010 the RDI showed the highest value. These data show how the restitution of $80 \%$ of the $\mathrm{ET}_{\mathrm{c}}$ losses during the period of flowering of the first truss to fruit breaking colours of the first truss $\left(\mathrm{PS}_{2}\right)$ might be beneficial for fruit weight under particular seasonal conditions. The lowest fruit weight was always obtained for the DI regime, which is in agreement with Kuşçu et al. (2014), who reported that low fruit weight is related to soil moisture level; if the soil is dry for a long time, the fruit water content will also be low.

Finally, significant correlations between the marketable yield and the physiological parameters evaluated in the $\mathrm{PS}_{2}$ stage were found. In particular, the marketable yield was negatively correlated with CTD $(-0.489)$ and positively with stomatal conductance $(0.49)$; these results indicate that both of these physiological parameters evaluated in the $\mathrm{PS}_{2}$ phenological stage can give important information about the final yield response.

High soluble solids content is an important quality factor for the tomato industry, because of the lower quantities of energy that are necessary to evaporate off the water from the fruit when producing tomato paste or concentrated tomato juice (Johnstone et al., 2005; Patanè and Cosentino, 2010). In the first year the FaI produced fruits with soluble
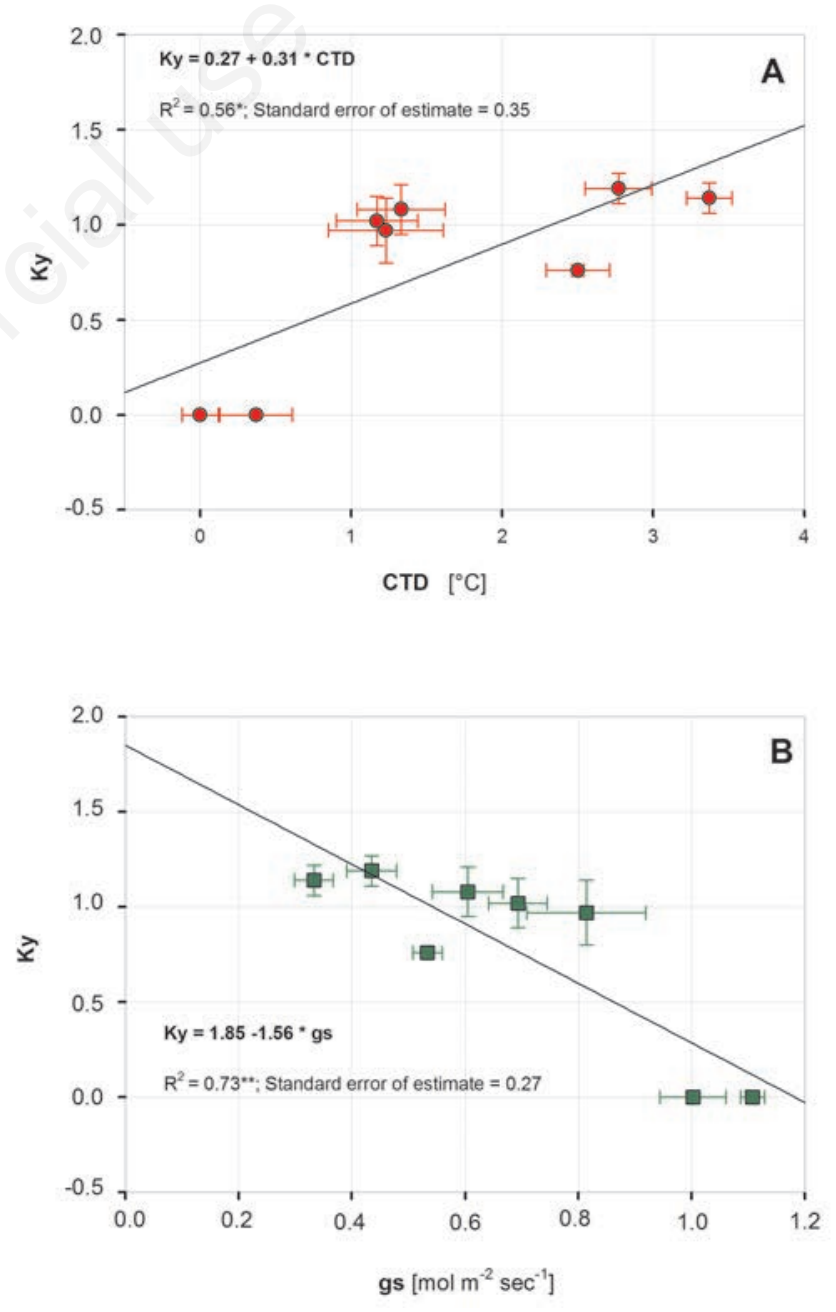

Figure 3. Yield response factor $\left(K_{y}\right)$ versus the physiological parameters: A) canopy temperature depression (CTD); and B) stomatal conductance (gs). Data are means \pm standard error. $R^{2}=$ determination coefficient; ${ }^{* *} \mathbf{P}<0.01$. 
solids that were lower than the minimum level allowed by the industry for acceptable fruit $\left(5^{\circ}\right.$ Brix) (Marouelli et al., 1991), while for the other irrigation treatments, the soluble solids were always higher. In 2009, the RDI and DI regimes showed the higher soluble solids, while in 2010 , the highest soluble solids value was observed for the DI regime. This different result is probably due to the different climatic conditions that characterised the two years under study as widely reported in the literature (Nuruddin et al., 2003; Zegbe-Domínguez et al., 2003; Favati et al., 2009; Patanè and Cosentino, 2010; Patanè et al., 2011; Kuşçu et al., 2014). Moreover, in 2010, the lack of significance in the differences of the soluble solids between RDI and FI regime, is in agreement with Hanson et al. (2006), who did not find any statistical differences between the soluble solids of tomato that were well irrigated and tomato cultivated under water deficit. These data imply that the soluble solids content of tomato depends on the period of water stress rather than the amount of water applied. Moreover, Rodriguez et al. (1994) reported that the soluble solids can be very dynamic, in that they can differ between sites and years.

\section{Relative yield decrease}

The yield response factor has been calculated in order to evaluate the sensitivity of the tomato to the evapotranspiration deficit. The $\mathrm{K}_{\mathrm{y}}$ connects the relative decrease in yield to the relative evapotranspiration deficit, and its specific value changes according to the crop species and cultivar, the irrigation method, and the crop management (Singh et al., 2010). A $\mathrm{K}_{\mathrm{y}}>1.0$ identifies sensitivity to water stress and indicates, for a given evapotranspiration deficit, that the expected relative yield decrease is proportionately greater than the relative decrease in evapotranspiration. Conversely, a $\mathrm{K}_{\mathrm{y}}<1.0$ identifies crops tolerant to water stress and indicates exactly the opposite behaviour. Under our experimental conditions, $\mathrm{K}_{\mathrm{y}}$ was slightly lower than 1.0 and equal to 0.91 indicating a productivity behaviour that allows a reduced water supply with low effects on yield. This is similar to the $\mathrm{K}_{\mathrm{y}}$ reported in our previously studies (Giuliani et al., 2011; Nardella et al., 2012), and also to that of Patané et al. (2011), who reported a $\mathrm{K}_{\mathrm{y}}$ of 0.76 . On the other hand, Doorenbos and Kassam (1979) estimated the $\mathrm{K}_{\mathrm{y}}$ for tomato as 1.05 , thus classifying their tomato crop as moderately sensitive to water stress. Moreover, in processing tomato field experiments conducted in some Mediterranean areas as Turkey (Kuşçu et al., 2014) and Italy (Perniola et al., 2005; Cantore et al., 2016) a $\mathrm{K}_{\mathrm{y}}$ higher than 1.4, indicating high crop sensitivity to water stress, was observed. It appears likely that the different data reported in the literature for $\mathrm{K}_{\mathrm{y}}$ in tomato are closely related to the different cultivars and to the different environmental and seasonal conditions, and growth stage when deficit evapotranspiration is imposed (Kaboosi and Kaveh, 2012).

Finally, linear regression was found between $\mathrm{K}_{\mathrm{y}}$ and the physiological parameters (Figure $3 \mathrm{~A}, \mathrm{~B}$ ). $\mathrm{K}_{\mathrm{y}}$ was positively related to $\mathrm{CTD}$, which indicates that if the CTD measured in the $\mathrm{PS}_{2}$ stage increases, the final yield response factor will also increase. The contrary applies to stomatal conductance, which was highly and negatively related to $\mathrm{K}_{\mathrm{y}}$. These data show that under our experimental conditions, better physiological behaviour of the plant in $\mathrm{PS}_{2}$, especially through the correct degree of stomata opening, can increase the plant stress tolerance level, and thus influence the final $K_{y}$ value.

\section{Conclusions}

The data obtained in the present study demonstrate that in Southern Italy the irrigation planning followed by the farmer does not follow the principles of sustainable irrigation. Indeed, the farmer tends to over- irrigate the tomato crop and a portion of this water is given without significant increment in the marketable fruit yield and with lower quality of fruits. Among the water regimes used, RDI showed constant yield values over the 2009 and 2010, although 2010 was climatically less favourable; conversely, this climatic stress reduced the marketable yield under the full-irrigated regime. These results are of particular interest in Mediterranean environment characterised by a high climatic variability. Our data showed that with the RDI strategy, it is possible to save about $27 \%$ of water with high $\mathrm{WUE}_{\mathrm{y}}$ value and an increase of fruit quality and confirms the possibility of saving water in both the vegetative and ripening periods under this Mediterranean climate. Finally, $\mathrm{K}_{\mathrm{y}}$ was 0.91 , indicating moderate tomato tolerance to water stress in our climate conditions.

\section{References}

Allen RG, Pereira LS, Raes D, Smith M, 1998. Crop evapotranspiration: Guidelines for computing crop water requirements. Irrigation and Drainage Paper no. 56. FAO, Rome, Italy.

Bahar B, Yildirim M, Barutcular C, Genc I, 2008. Effect of canopy temperature depression on grain yield and yield components in bread and durum wheat. Not. Bot. Horti Agrobo. 36:34-7.

Benton Jr JJ, 2007. Tomato plant culture in the field, greenhouse, and home garden. CRC Press, Boca Raton, FL, USA.

Bőcs A, Pék Z, Helyes L, Neményi A, Komjáthy L, 2009. Effect of water supply on canopy temperature and yield of processing tomato. Cereal Res. Comm. 37:113-6.

Cantore V, Lechkar 0, Karabulut E, Sellami MH, Albrizio R, Boari F, Stellacci AM, Todorovic M, 2016. Combined effect of deficit irrigation and strobilurin application on yield, fruit quality and water use efficiency of "cherry" tomato (Solanum lycopersicum L.). Agric. Water Manage. 167:53-61.

Chen J, Kang S, Du T, Qiu R, Guo P, Chen R, 2013. Quantitative response of greenhouse tomato yield and quality to water deficit at different growth stages. Agric. Water Manage. 129:152-62.

Doorenbos J, Kassam AH, 1979. Yield response to water. Irrigation and Drainage Paper no. 33. FA0, Rome, Italy.

El-Hendawy SE, Schmidhalter U, 2010. Optimal coupling combinations between irrigation frequency and rate for drip-irrigated maize grown on sandy soil. Agric. Water Manage. 97:439-48.

Favati F, Lovelli S, Galgano F, Miccolis V, Di Tommaso T, Candido V, 2009. Processing tomato quality as affected by irrigation scheduling. Sci. Hortic. 122:562-71.

Fereres E, Soriano MA, 2007. Deficit irrigation for reducing agricultural water use. J. Exp. Bot. 58:147-59.

García-Tejero IF, Durán-Zuazo VH, Muriel-Fernández JL, RodríguezPleguezuelo CR, 2011. Water and sustainable agriculture. Springer, New York, USA.

Giuliani MM, Nardella E, Gatta G, De Caro A, Quitadamo M, 2011. Processing tomato cultivated under water deficit conditions: the effect of azoxystrobin. Acta Hort. 914:287-94.

Hanson BR, Hutmacher RB, May DM, 2006. Drip irrigation of tomato and cotton under shallow saline ground water conditions. Irrig. Drainage Syst. 20:155-75.

Idso SB, Jackson RD, Pinter Jr PJ, Reginato RJ, Hatfield JL, 1981. Normalizing the stress degree day for environmental variability. Agric. Meteorol. 24:45-55.

Istanbulluoglu A, Gocmen E, Gezer E, Pasa C, Konukcu F, 2009. Effects of water stress at different development stages on yield and water productivity of winter and summer safflower (Carthamus tinctorius L.). Agric. Water Manage. 96:1429-34. 
Jensen ME, Burman RD, Allen RG, 1990. Evapotranspiration and irrigation water requirements. ASCE Manuals and reports on engineering practice no. 7. ASCE, New York, USA.

Johnstone PR, Hartz TK, LeStrange M, Nunez JJ, Miyao EM, 2005. Managing fruit soluble solids with late-season deficit irrigation in drip-irrigated processing tomato production. HortSci. 40:1857-61.

Kaboosi K, Kaveh F, 2012. Sensitivity analysis of FAO 33 crop water production function. Irrigation Sci. 30:89-100.

Kuşçu H, Turhan A, Demir A0, 2014. The response of processing tomato to deficit irrigation at various phenological stages in a subhumid environment. Agric. Water Manage. 133:92-103.

Lovelli S, Perniola M, Ferrara A, Di Tommaso T, 2007. Yield response factor to water $\left(\mathrm{K}_{\mathrm{y}}\right)$ and water use efficiency of Carthamus tinctorius L. and Solanum melongena L. Agric. Water Manage. 92:73-80.

Marouelli WA, Silva HR, Oliveira CAS, 1991. Production of industrial tomato under different soil moisture regimes. Pesqui. Agropecu. Bras. 26:1531-37.

Marouelli WA, Silva WLC, 2007. Water tension thresholds for processing tomatoes under drip irrigation in Central Brazil. Irrigation Sci. 25:411-8.

Nardella E, Giuliani MM, Gatta G, De Caro A, 2012. Yield response to deficit irrigation and partial root-zone drying in processing tomato (Lycopersicon esculentum Mill.). J. Agric. Sci. Technol. A 2:209-19.

Nuruddin MM, Madramootoo CA, Dodds GT, 2003. Effects of water stress at different growth stages on greenhouse tomato yield and quality. HortSci. 38:1389-93.

Patanè C, Cosentino SL, 2010. Effects of soil water deficit on yield and quality of processing tomato under a Mediterranean climate. Agric. Water Manage. 97:131-8.

Patanè C, Tringali S, Sortino 0,2011 . Effects of deficit irrigation on biomass, yield, water productivity and fruit quality of processing tomato under semi-arid Mediterranean climate conditions. Sci. Hortic. 129:590-6.

Perniola M, Lovelli S, Pizza S, Caponio T, Ferrara A, 2005. Scelta del criterio di programmazione irrigua per ottimizzare l'uso della risorsa idrica. pp 212-213 in Atti del XXXVI Convegno della Società Italiana di Agronomia, Foggia, Italy.

Rinaldi M, Garofalo P, Rubino P, Steduto P, 2011. Processing tomatoes under different irrigation regimes in Southern Italy: agronomic and economic assessments in a simulation case study. Ital. J. Agrometeorol. 3:39-56.

Rinaldi M, Rana G, 2004. Water use of processing tomato in the
Capitanata Region (Southern Italy). Riv. Ital. Agrometeorol. 1:31-5. Rodriguez A, Leoni S, Bussieres P, Dadomo M, Christou M, Macua IJ, Cornillon P, 1994. The influence of water and nitrogen levels on the quality of the processing tomato grown in European Union Countries. Acta Hort. 376:275-8.

Savic S, Stikic R, Zaric V, Vucelic-Radovic B, Jovanovic Z, Marjanovic M, Djordjevic S, Petkovic D, 2011. Deficit irrigation technique for reducing water use of tomato under polytunnel conditions. J. Cent. Eur. Agr. 12:590-600.

Singh Y, Rao SS, Regar OL, 2010. Deficit irrigation and nitrogen effects on seed cotton yield, water productivity and yield response factor in shallow soils of semi-arid environment. Agric. Water Manage. 97:965-70

Sobeih WY, Dodd IC, Bacon MA, Grierson D, Davies WJ, 2004. Long-distance signals regulating stomatal conductance and leaf growth in tomato (Lycopersicon esculentum) plants subjected to partial rootzone drying. J. Exp. Bot. 55:2353-63.

Stewart JI, Cuenca RH, Pruitt WO, Hagan RM, Tosso J, 1977. Determination and utilisation of water production functions for principal California crops. University of California, W-67 Calif. Contrib. Proj. Rep., Davis, USA.

Tarantino E, Onofri M, 1991. Determinazione dei coefficienti colturali mediante lisimetri. Bonifica 7:119-36.

Topcu S, Kirda C, Dasgan Y, Kaman H, Cetin M, Yazici A, Bacon MA, 2007. Yield response and $\mathrm{N}$ fertiliser recovery of tomato grown under deficit irrigation. Eur. J. Agron. 26:64-70.

Wang W-J, Wang T-L, Bo L, 2015. Effect of water-fertilizer coupling on yield, quality and soil nutrient content of tomato in greenhouse. In: L. Xie (Ed.), Advanced engineering and technology II. CRC Press/Balkema, Leiden, The Netherlands, pp 129-133.

Zegbe JA, Behboudian MH, Clothier BE, 2006. Yield and fruit quality in processing tomato under partial rootzone drying. Eur. J. Hortic. Sci. $71: 252-8$

Zegbe-Domínguez JA, Behboudian MH, Lang A, Clothier BE, 2003. Deficit irrigation and partial root-zone drying maintain fruit dry mass and enhance fruit quality in 'Petopride' processing tomato (Lycopersicon esculentum Mill.). Sci. Hortic. 98:505-10.

Zheng J, Huang G, Jia D, Wang J, Mota M, Pereira LS, Huang Q, Xu X, Liu H, 2013. Responses of drip irrigated tomato (Solanum lycopersicum L.) yield, quality and water productivity to various soil matric potential thresholds in an arid region of Northwest China. Agric. Water Manage. 129:181-93. 